\title{
HYDROLOGICAL AND MECHANICAL PROPERTIES OF LOESS LANDSLIDES UNDER DIFFERENT VEGETATION RESTORATION TYPES
}

\author{
LeI SHI ${ }^{1,2}$, ZhONGZHENG LiU ${ }^{3 *}$ AND LiANGYAN Y ANG $^{1,2}$ \\ Shaanxi Provincial Land Engineering Construction Group Co. Ltd., \\ Xi'an, Shaanxi, 710075, China
}

Keywords: Loess landslide, Vegetation restoration, Soil mechanical properties

\begin{abstract}
Loess landslide is a common geological disaster in northern Shaanxi, which seriously affects people's life and property safety and social and economic development. The research on vegetation restoration types and hydrological and mechanical properties of loess landslides can provide basic data support for landslide stability prediction, and further provide reference for landslide prevention and treatment. In the present study, the loess landslide point of Zhang Zi Gou in Gan Quan County, Yan' an City was taken as the research object. On the basis of the existing natural condition data, the basic physical and mechanical properties and hydrological characteristics were obtained by collecting field landslide soil samples for indoor experimental analysis. The indoor analysis shows that the landslide is mainly distributed in dry land, medium coverage and low coverage grassland, indicating that the surface vegetation coverage can affect the stability of landslide. The worse the vegetation coverage, the more landslides occur. The void ratio and porosity of landslide soil decrease with the increase of dry density. The cohesion of natural soil is obviously higher than that of saturated soil, and the internal friction angle of natural soil is slightly lower than that of saturated soil. In general, due to the influence of water content, the shear strength of natural soil samples is higher than that of saturated soil samples. Therefore, in order to improve the accuracy of prediction and early warning system, it is necessary to consider the response of hydrological and mechanical properties of loess to vegetation restoration. The results provide basic data support for the establishment of loess landslide stability prediction system and provide reference for geological disaster management.
\end{abstract}

\section{Introduction}

Loess landslides are a common type of geological hazard in loess hilly and gully regions. Shaanxi Province, as the central accumulation area of the Loess Plateau, covers $40 \%$ of the total area of the province. Loess landslides occur frequently, which seriously affects people's lives in the region, safety of life and property and economic development ( $\mathrm{Pu} \mathrm{2008,} \mathrm{Zhang} \mathrm{et} \mathrm{al.} \mathrm{2016).}$ The cost of landslide prediction and early warning means is low, and the corresponding is relatively fast, which is a hot spot in the field of geological disaster research in recent years (Zhuang et al. 2013). The establishment of a prediction and early warning mechanism for loess landslides has been included in the key objectives of the geological disaster prevention and control plan of Shaanxi Province (Gao et al. 2019). Therefore, in view of the actual situation of the Loess Plateau in northern Shaanxi and under the new geological engineering conditions brought about by the restoration of the vegetation environment, the establishment of a corresponding loess landslide prediction and early warning system is an urgent task for the current disaster prevention and control work. This not only helps to deepen and improve the understanding of the ecological

*Author for correspondence c: <610529300@qq.com>. ${ }^{1}$ Key Laboratory of Degraded and Unused Land Consolidation Engineering, the Ministry of Land and Resources, Xi' an, Shaanxi, 710075, China. ${ }^{2}$ Institute of Land Engineering and Technology, Shaanxi Provincial Land Engineering Construction Group Co. Ltd., Xi' an, Shaanxi, 710075, China. ${ }^{3}$ Land Surveying, Planning and Design Institute of Shaanxi Provincial Land Engineering Construction Group Co., Ltd., Xi'an 710075, China. 
environment of the Loess Plateau in northern Shaanxi, but also provides a reference for the management of geological disasters and promotes the process of country's ecological civilization construction (Shen et al. 2010, Duan et al. 2012).

Vegetation change in loess area is often ignored by the traditional loess landslide prediction and early warning system. After a series of ecological restoration measures such as "returning farmland to forest and grassland" promulgated in 2000, the vegetation coverage rate in the loess hilly and gully region was significantly improved. The benign development of ecological environment construction has greatly reduced the number of geological disasters in loess hilly and gully areas, and successfully avoided a large number of casualties and economic losses. Great achievements have been made in disaster prevention and mitigation. At the same time, with the ecological restoration and the increase of vegetation coverage, the development characteristics and distribution of geological disasters in loess hilly and gully areas have also changed to some extent (Wang et al. 2009). Under the background of ecological restoration and increasing vegetation in loess area in China, the root characteristics and water holding capacity of loess jointly determine that the effect of loess landslide prediction and early warning system may be more sensitive to vegetation (Peng et al. 2010). Therefore, in order to improve the accuracy of prediction and early warning system, it is necessary to consider the response of loess hydrological and mechanical properties to vegetation restoration, and combine the spatial distribution of vegetation conditions with the detailed investigation results of hidden danger points.

As an effective disaster prevention and mitigation measure, landslide stability prediction mechanism is of great significance to loess area. Due to ignoring the spatial differences of vegetation conditions and geological engineering conditions in different regions, the existing prediction and early warning methods are difficult to achieve the desired results in practical applications (Zhang et al. 2015). Based on the vegetation cover, soil hydrological and mechanical properties and geomechanical characteristics, this study provides basic data support for the establishment of loess landslide stability prediction system (Wang et al. 2003, Wang and Liu 2002). The research results can be applied to the loess landslide disaster prevention and mitigation project in the loess plateau to promote the construction of ecological civilization.

\section{Materials and Methods}

GanQuan County located in the central area of Yan'an City, Shaanxi Province $\left(108^{\circ} 45^{\prime} 34^{\prime \prime E}\right.$ $109^{\circ} 33^{\prime} 46^{\prime \prime} \mathrm{E}, 36^{\circ} 6^{\prime} 57^{\prime \prime} \mathrm{N}-109^{\circ} 33^{\prime} 46^{\prime \prime} \mathrm{N}$ ) is a typical hilly and gully landform on the Loess Plateau in northern Shaanxi, with an altitude of $950-1625 \mathrm{~m}$ (Fig. 1). It has a semi-humid inland monsoon climate with an average annual temperature of $8.6^{\circ} \mathrm{C}$, an average of $6.8 \mathrm{hrs}$ of sunshine, and an annual rainfall of $126.3 \mathrm{~mm}$. The county covers an area of $2284.7 \mathrm{~km}^{2}$, with a forest and grass coverage rate of 78.4\%, which belongs to zonal vegetation (Han Shifeng et al. 1999).

The Zhangzigou landslide in the study area is located in Yaozi Village $\left(109^{\circ} 21^{\prime} 53^{\prime \prime} \mathrm{E}\right.$, $36^{\circ} 17^{\prime} 55 \mathrm{~N}$ ), Sansheng Township, Shimen Town, Ganquan County. The overall slope is about $30^{\circ}$, the east-west length is about $95 \mathrm{~m}$, the north-south length is about $170 \mathrm{~m}$. The relative height difference of the landslide is about $87 \mathrm{~m}$, the average thickness of the landslide is about $11 \mathrm{~m}$, and the volume is about $170,000 \mathrm{~m}^{3}$. After the landslide, there are grass and bushes. The vegetation coverage on the surface of the landslide is in good condition, and the most species of vegetation are Compositae and Rosaceae. The stratigraphic structure is divided into the Quaternary Upper Pleistocene loess at the rear edge of the landslide, and the main body of the landslide is the Quaternary Upper Pleistocene accumulation Loess, thick layered feldspar sandstone with sliding bed, is a typical loess-bedrock type landslide (Zhang and Zhang 2000). 


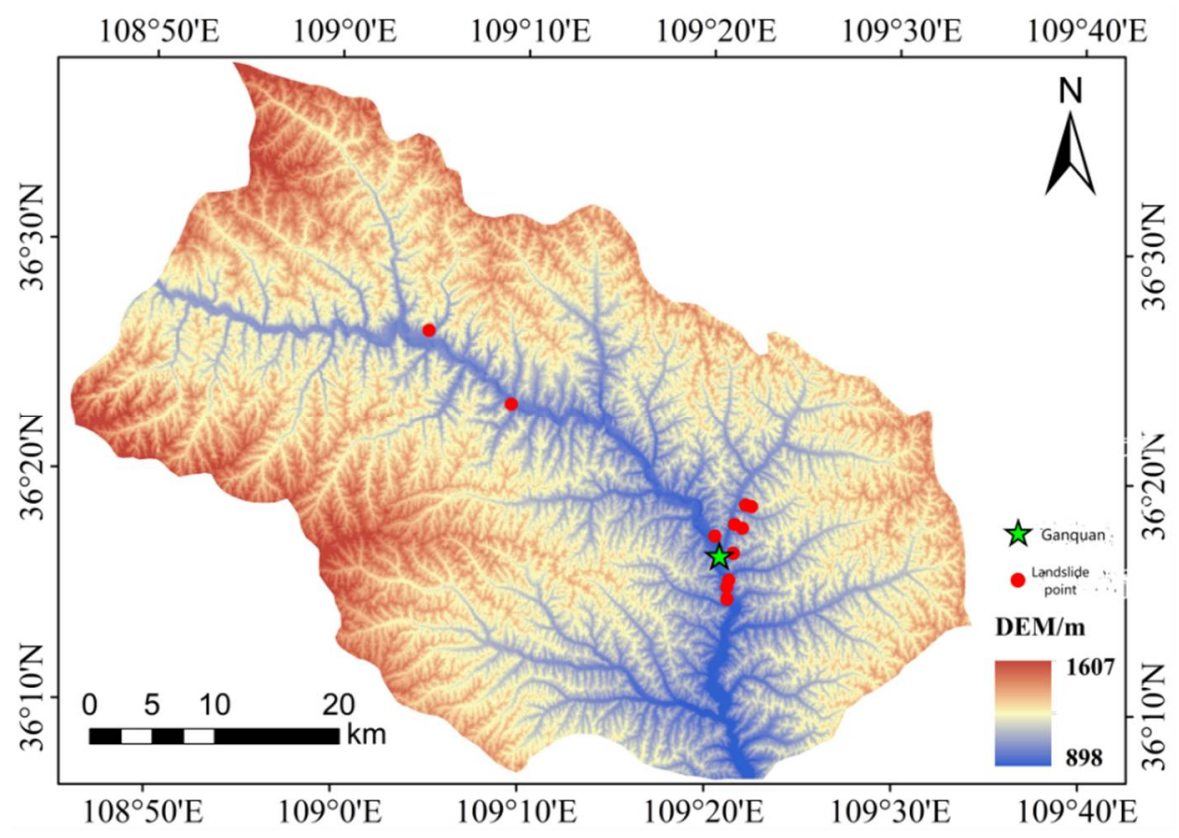

Fig. 1. Landslide point distribution map in Ganquan County.

Firstly, the MODIS satellite data before, during and after vegetation restoration were used to invert the vegetation cover in the area, and the changes of vegetation cover in the area were evaluated and analyzed macroscopically. MODIS is a spatial remote sensing instrument developed and manufactured by NASA, which can provide $250 \mathrm{~m}$ spatial resolution vegetation index data products and can be downloaded for free. After field investigation, the plant species, quantity, density information and root distribution in the region were counted. The typical loess landslide hazard points in the region were selected to take loess soil samples (Yang et al. 2006). The hydrological and mechanical parameters were measured in the laboratory, and compared with the previously used parameters for the landslide in the literature. The causes of the differences were discussed based on the vegetation characteristics obtained from the analysis ( $\mathrm{Li}$ 2017).

\section{Results and Discussion}

According to a thorough investigation of the flora in the study area, there are 41 common plant species. Most of the species belong to the warm temperate zone. There are 9 species of Compositae and Rosaceae, accounting for $40 \%$ of the total species (Lei 1999) followed by legumes (Leguminosae) 5 species, accounting for $11.1 \%$. In the flora composition, there are 14 families of 1 to 2 plant species, accounting for $48.8 \%$ of the total, indicating that the vegetation in the study area is dominated by plants of certain families and the community is relatively simple. The community in the study area is divided into three basic levels: tree layer, shrub layer, and herb layer. Among them, most of the herbaceous plants are Potentilla chinensis Ser., Artemisia sacrorum Ledeb., etc.; the shrub layer plants mainly include Sophora davidii (Franch.) Skeels, and Tamarix ramosissima Ledeb, etc. There are a few types of arbor layer plants, such as elm (Ulmus pumila L.), Peach (Amygdalus persica L.), etc. 
Table 1. The composition of different vegetation communities on the plot.

\begin{tabular}{|c|c|c|c|c|}
\hline $\begin{array}{l}\text { Vegetation community } \\
\text { type }\end{array}$ & Aspect & $\begin{array}{l}\text { Altitude/ } \\
\mathrm{m}\end{array}$ & $\begin{array}{l}\text { Slope/ } \\
\left({ }^{\circ}\right)\end{array}$ & Other vegetation \\
\hline $\begin{array}{l}\text { I }(\text { Potentilla }+ \\
\text { Caragana })\end{array}$ & $\mathrm{S} 15^{\circ} \mathrm{W}$ & 1290.3 & 26 & $\begin{array}{l}\text { Artemisia alba, Asparagus, Wild chrysanthemum, } \\
\text { Aster, Thalictrum, Cylindrica }\end{array}$ \\
\hline $\begin{array}{l}\text { II (Astragalus + } \\
\text { Potentilla) }\end{array}$ & $\mathrm{S} 15^{\circ} \mathrm{W}$ & 1284.9 & 38 & $\begin{array}{l}\text { Rehmannia, White lotus, Wild chrysanthemum, } \\
\text { Aster, Lanceolate wild cassia }\end{array}$ \\
\hline $\begin{array}{l}\text { III }(\text { Caragana }+ \\
\text { Nitraria })\end{array}$ & $\mathrm{S} 15^{\circ} \mathrm{W}$ & 1275.1 & 29 & $\begin{array}{l}\text { Asparagus, Thalictrum, Astragalus, Nitraria, } \\
\text { Cassia lanceolata, Zelkova }\end{array}$ \\
\hline IV (Caragana) & $\mathrm{S} 15^{\circ} \mathrm{W}$ & 1263.02 & 53 & $\begin{array}{l}\text { Rehmannia glutinosa, Wild chrysanthemum, } \\
\text { Aster, Thalictrum lanceolata, Wild cassia } \\
\text { lanceolata, Photinia glabra, Polygonatum, Crab } \\
\text { grass, Gentian, Elm, Peach }\end{array}$ \\
\hline
\end{tabular}

Through the investigation of the land cover types of different vegetation communities in the study area, it is apparent from Fig. 2 that with the increase of plant species diversity, the surface vegetation coverage has increased significantly, and the number of surface litters has gradually increased (Wang and Ren 2008). Surface vegetation is composed of lower organisms, such as moss and lichens. The appearance of these plant species shows that under the cover of perennial vegetation, the local microenvironment has been fundamentally improved. With the increase of vegetation type and ground vegetation coverage, the number of bare land and crusts decreases, and the ground covered by vegetation I-IV is close to natural Grassland covered by vegetation. According to the effects of different types of cover on soil erosion, it may be concluded that the effects of biological crusts and bare land on soil erosion are similar, while the effects of ground vegetation, litter and vegetation on soil erosion are also similar. Therefore, when calculating the surface coverage, the coverage of living vegetation, litter and living vegetation is combined into the surface coverage.

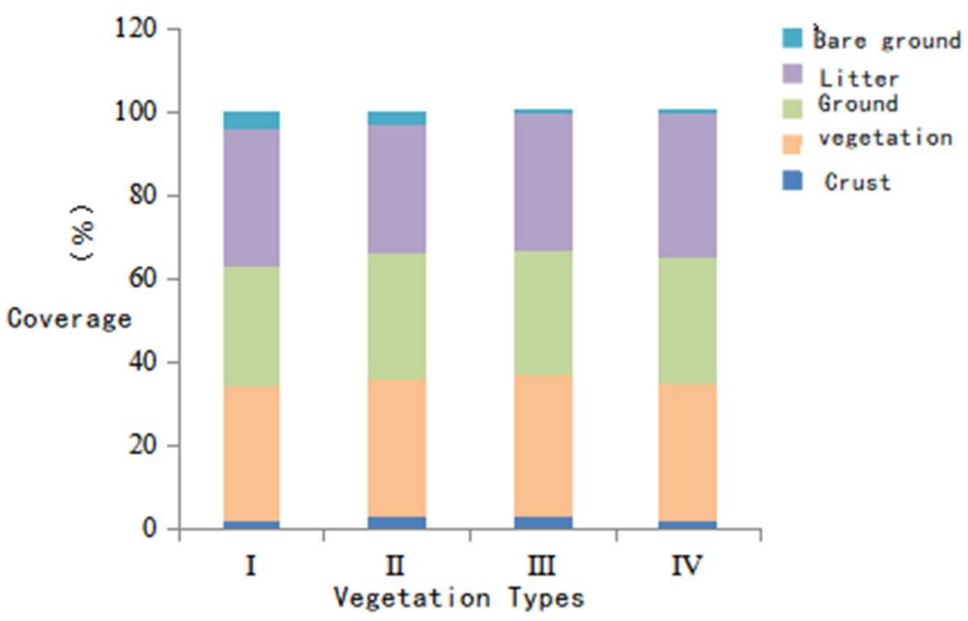

Fig. 2. Distribution characteristics of land cover in different vegetation communities. 
According to the test of soil samples collected in the study area, the measurement results of soil moisture content and density are presented in Table 2. It can be seen that the soil natural moisture content in the study area was $13.65-16.82 \%$, the saturated moisture content was 23.08 $32.95 \%$, and the natural density was $1.43-1.83 \mathrm{~g} / \mathrm{cm} 3$, the saturated density was $1.82 \sim 2.08$ $\mathrm{g} / \mathrm{cm} 3$, the dry density was $1.23 \sim 1.61 \mathrm{~g} / \mathrm{cm} 3$, the void ratio was between $0.70 \sim 1.15$, and the porosity was between $39.7 \sim 53.2 \%$. Through experiments, it was determined that the vegetation community of IV had the least soil water content, less pores, and the highest natural density and saturated density. The vegetation community of II had larger soil water content, loose soil, and the ratio of pores and the porosity was larger, and the natural density and saturated density were smaller. The porosity ratio and porosity increased, the dry density decreased. The porosity ratio and the porosity value were in order of IV $<$ I $<$ III $<$ II, and the order of the dry density value was $\mathrm{II}<\mathrm{I}<\mathrm{III}<\mathrm{IV}$; The pores were relatively large, 1.09 and 1.15 , respectively; II natural moisture content was the largest; saturated density and dry density were small (Yang 2015).

The experiment shows that the soil permeability coefficient in the study area was between $0.52 \sim 1.45 \mathrm{~mm} / \mathrm{min}$, and the vertical soil permeability coefficient was: II $<$ I $<$ III $<$ IV (Table 2 ). The water permeability of III and IV was better, and conducive to the infiltration of rainwater. In addition, the sinkhole in III was also conducive to the rapid infiltration of rainwater into the soil. In one hand, it increases the weight of the slope and on the other hand makes the soil more resistant. The shear strength is reduced (Yang et al. 2010).

Table 2. The composition of different vegetation communities on the plot.

\begin{tabular}{lccccc}
\hline $\begin{array}{l}\text { Community } \\
\text { type }\end{array}$ & $\begin{array}{c}\text { Natural moisture } \\
\text { content } \%\end{array}$ & $\begin{array}{c}\text { Saturated moisture } \\
\text { content } \%\end{array}$ & $\begin{array}{c}\text { Saturated moisture } \\
\text { content } \mathrm{g} / \mathrm{cm}^{3}\end{array}$ & $\begin{array}{c}\text { Saturation } \\
\text { density } \mathrm{g} / \mathrm{cm}^{3}\end{array}$ & $\begin{array}{c}\text { Porosity } \\
(\%)\end{array}$ \\
\hline I & 14.22 & 32.95 & 1.44 & 1.85 & 52.6 \\
II & 16.82 & 32.56 & 1.43 & 1.82 & 53.2 \\
III & 14.84 & 26.17 & 1.49 & 1.83 & 50.1 \\
IV & 13.65 & 23.08 & 1.83 & 2.08 & 39.7 \\
\hline
\end{tabular}

By fitting the changes of soil strength parameters under different normal stresses, the shear strength envelope of natural soil and artificially intervention saturated landslide soil was obtained (Fig. 3, c represents cohesion and $\varphi$ represents internal friction angle). It can be seen from the Figure that the maximum cohesion of natural soil samples was $19.93 \mathrm{kpa}$ and the minimum was $11.33 \mathrm{kpa}$; the range of internal friction angle was $32.82 \sim 34.31^{\circ}$; while the cohesion of saturated soil samples was the maximum of $10.5 \mathrm{kpa}$ and the minimum was $2.1 \mathrm{kpa}$; The range of internal friction angle was $33.9 \sim 35.56^{\circ}$. In general, the shear strength of saturated soil was found to be lower than that of natural soil. The cohesion of saturated soil samples of different vegetation communities was much lower than that of natural soil samples, reducing $5.86 \sim 16.26 \mathrm{kpa}$; the internal friction angle of saturated soil has a slight increase compared with natural soil, increasing by $0.2 \sim 2.74^{\circ}$. Soil moisture will significantly affect the shear strength thereof, IV compacting soil, water content was less, and therefore under the same pressure, and its natural soils saturated shear strength greater. According to the relationship between water content and cohesion of soil samples (Fig. 4), it can be seen that the cohesion will decrease with the increase of water content. 

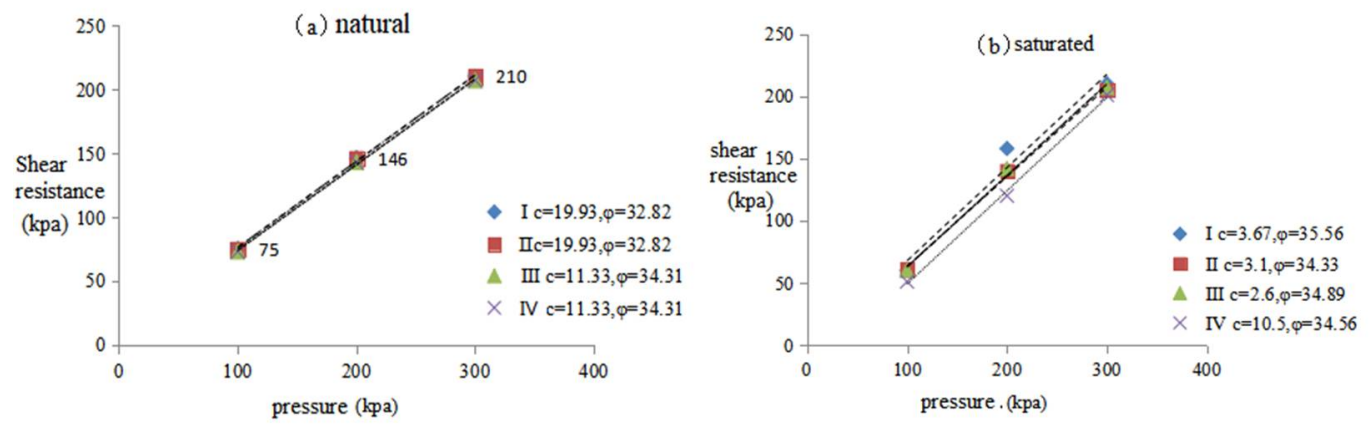

Fig. 3. Envelope of residual shear strength of natural and saturated landslide soil.

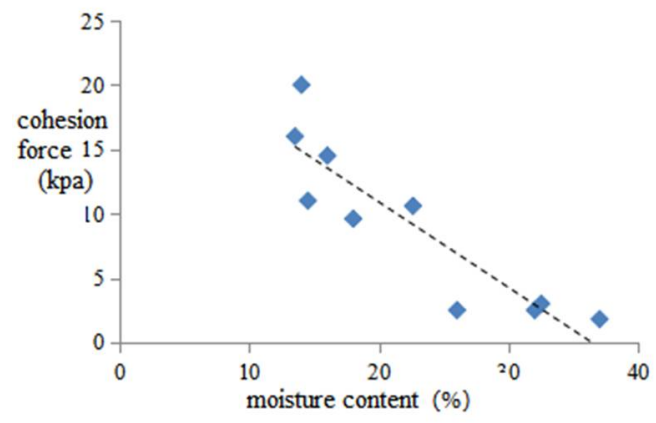

Fig. 4. Relationship between water content and cohesion.

In the present study, the disaster area of ZhangZiPo in GanQuan County was taken as the research object. The following conclusions may be drawn from field investigation and indoor analysis: (i) Landslides are mainly distributed in dry land, medium coverage and low coverage grassland, indicating that the surface vegetation coverage can affect the stability of landslides, and the worse the vegetation coverage is the more landslides occur. (ii) The basic mechanical properties of landslide soil showed that the void ratio and porosity decreased with the increase of dry density. The cohesion of natural soil was significantly higher than that of saturated soil, and the internal friction angle of natural soil was slightly lower than that of saturated soil. In general, due to the influence of water content, the shear strength of natural soil samples was higher than that of saturated soil samples.

\section{Acknowledgements}

The project was supported by the project of Shaanxi Provincial Land Engineering Construction Group (DJNY2020-30 and DJNY2021-33).

\section{References}

Duan Z, Zhao FQ and Li F 2012. Spatial differentiation characteristics of landslide disasters in Shaanxi Province based on GIS. Disaster, 1: 34-37.

Gao J L, Zhang J G et al. 2019. Change characteristics of key soil and water conservation measures in loess hilly and gully regions. Soil and Water Conser. Brief. 039(003): 114-118. 
Han S F, Li Y S, Shi Y J et al. 1999 Characteristics of soil moisture resources in the Loess Plateau. Soil and Water Conser. Brief. 10(1): 36-43.

Lei M D 1999. Shaanxi Vegetation. Beijing: Science Press, 125.

Li N 2017. Mechanism of rainfall-induced loess landslides in northern Shaanxi. Xi'an: Xi'an University of Architecture and Technology.

Peng L, Niu RQ and Chen LX 2010. Spatial prediction of landslide disasters in Zigui County, Three Gorges Reservoir Area supported by GIS. Geograp. Res. 29(10): 1889-1898.

$\mathrm{Pu}$ SR 2008. Constraints and inducing factors of loess landslides in Shaanxi. Resour. Environ. Engin. 22: 133-136.

Shen RC, Wu XQ and Zhu QK 2010. Optimal allocation of suitable plant communities in loess areas - A case study of Wuqi County, Yan'an City, Shaanxi Province. Resour. Environ. Arid Areas, 2010(04): 152-157.

Wang GL and Liu GB 2002. Soil water stable aggregate effect of vegetation restoration in Loess Hilly and gully area. J. Soil Water Conser. 16 (1): 48-50.

Wang GL, Liu GBa and Zhou SL 2003. The effect of vegetation restoration on soil stable infiltration in small watershed of loess hilly and gully region. J. Natural Resour. 18(5): 529-535.

Wang L, Wei SP and Wu FQ 2009. Soil heat status and vegetation growth response of agroforestry grassland in Loess Hilly and Gully Region - Taking Yangou watershed as an example. J. Ecol. 2009(12): 65786588.

Wang XF and Ren ZY 2008. The dynamic change of vegetation coverage in Yulin City based on RS and GIS. J. Shaanxi Normal Univer.: Nat. Sci. Edition 2008(03): 101-104.

Yang BQ 2015. Study on the characteristics and disaster-causing mechanism of loess landslide in Hetan village of south Jingyang plateau: Chang'an University.

Yang YH, Liu SZ and Wang CH 2006. Effects of soil water content and vegetation on shear strength of shallow landslide soil. Disaster 21 (2): 50-54.

Yang Z, Yuan JH and Ren Q et al. 2010 Study on Mechanism of loess landslide induced by cyclic load. Hydrogeology and Engineering Geology 037(005): 67-71.

Zhang CS and Zhang YC 2000. Spatial and temporal distribution characteristics and formation conditions of geological disasters in China. Quaternary Study 20(6): 559-566.

Zhang XY and Tao FP 2015. Genetic mechanism and stability analysis of loess landslide in Weibei plateau area - taking loess landslide in Chengbei Village, Hancheng City as an example. Geolog. Disasters Environ. Protection 26(002): 3-8.

Zhang YY 2016. Study on the formation mechanism of loess collapse in Yan'an area under rainfall. Xi'an University of Science and Technology.

Zhuang JQ, Peng JB and Zhang LY 2013. Risk prediction and evaluation of shallow landslide on the Loess Plateau under different rainfall conditions. J. Jilin Univer.: Geoscience Edition, 2013 (3): 867-876.

(Manuscript received on 19 May, 2021; revised on 27 August, 2021) 